\title{
On Unification of Functionality and Aesthetics of Design Art
}

\author{
Xiaoyu Zou \\ College of Art and Appareluages, Tianjin Polytechnic University \\ Tianjin 300387, China \\ E-mail: 13752061887@139.com
}

\begin{abstract}
Design art arises with development of great production in the industrial society. Design art is an independent and creative art activity. Modern design art is not only interrelated with aesthetic and visual formative form, but more emphasizes the functionality and creation pattern of design targets. Labor of designers is both spiritual production labor and material production labor. Works of design art is not only an article of utility which emphasizes function, but is also an artistic article with aesthetic significance.
\end{abstract}

Keywords: Functionality, Aesthetics, Design art

Design art arises with development of great production in the industrial society. As for the definition of the concept of design art, there are various opinions. In the $<<$ Encyclopedia of aesthetics $>>$ by Овсянников, there is such an explanation, "Design art is a creative activity, and its purpose is to formulate and adjust an object, in which process the functional and aesthetic aspects of the object are opposed to be unified". By the later period of Bauhaus, there appeared another refined explanation on the concept of technical design, "Design art is an aesthetic and materialized process which exists with the industrialization process of human beings". In the times of industrial informationization and information industrialization development, design is created by human being, which can not be replaced by mechanical production Creation potential of a designer is an extremely sophisticated psychological phenomenon, and is closely connected to social and historical elements.

Design art is an independent and creative art activity. Modern design art is not only interrelated with aesthetic and visual formative form, but more emphasizes the functionality and creation pattern of design targets. In other words, modern design art means that, in the modern industrial society of methods of mechanical production, at the time when a designer pays attention to the visual formative form and aesthetic effect of a designed object, he also lays emphasis on activities of the function of the designed object. Labor of designers is both spiritual production labor and material production labor. Works of design art is not only an article of utility which emphasizes function, but is also an artistic article with aesthetic significance.

Design art is a new artistic form brought into form in the process of art development, and is an artistic creation activity which starts from the perspective of utilitarian function. Design art weakens affective communication of individuality in pure art which emphasizes self-centeredness, and it also strengthens the function of public information transfer. It is just due to the certainty of this relation that design art is changed into a particular and generally recognized art form.

In a traditional meaning, design art is understood as an artisan craftsmanship, which overexaggerates the workmanship of design art. In the developmental process of design art, technique is, without doubt, an important component which constitutes the active process of technique. With the continual development of design art, art form exhibits a diversification developmental trend. New art forms continue to be brought into birth. In face of a variety of art forms, there also exist various viewpoints about understanding of the concept of design art. The reason for defining "design" as "design art" is that design art concentrates on the functional property of both aesthetics and utility.

To consider design art from the perspective of social development, it is a necessary product of human beings' demand on function and aesthetics in a particular era, and is brought into birth with development of the society and with evolution of technique. Considering from the perspective of design profession, art can be defined within the scope of "a combination of beauty and technique". At the time when the functionality is realized in the process of art activity, it also creates rules of beauty and forms of beauty. Design art resorts to new technique, new technology and new material to develop a great many sorts of design art with strong specialty. 
The essence of design art is a double combination of functionality and aesthetics. It is from the perspective of function that the earliest design starts. Therefore, this feature determines design art and is also a conscious creative activity process by human being. Design works are products created by human being with consciousness according to functionality and aesthetics.

With development of design art activities, it comes gradually to people's mind that, an entity with the rule of beauty on the basis of application is easy to arouse people's attention, and is more likely to be accepted by the public and to leave a perfect image. "Beauty" is a common character of all forms of art. The rule of beauty and the form of beauty in an art can better arouse attention of human being, and bring people into a sympathetic response because it can use accurate visual language to transmit particular information. Beauty is a common goal pursued by human being. The sense of pleasure in beauty comes from the cultural awareness of human being. And the form of beauty comes from the summary of experiences by human being in the process of their activities. In the nature, regular objects, symmetrical objects, orderly objects, pure objects or prismy objects are generally favored by human being. Therefore, in a certain meaning, people believe that these forms are what is called "beauty", because they are in accordance with psychological activities of the public. Hence, in the design art, such rules and forms of beauty are usually applied as regularity, symmetry, order, rhythm and meter etc. To create beauty in design art is an visual representation process of standardization and uniformity of visual elements. Within limited space, through the visual regularity and aesthetic habits of human being, beauty transmits particular information by organic combination of graphical language and word language so as to enable a designed object to better reflect the functionality. There are various means to create beauty in the design art. Firstly, summary of experiences in beauty, secondly, innovation of rules in beauty; thirdly, exploration in forms of beauty. No matter from which perspective, the purpose is to achieve the purpose of functionality so as to perform art creation.

In the developmental process of design art in China, these two properties are indiscerptible.

\section{Practicability of design:}

For quite a long time, the design art in China has regarded aesthetics and function as diametrically opposed rather than a unified whole, which results in the lagging behind of Chinese design art, especially architectural design and design of industrial products. In the $<<$ Technological Aesthetics $>>$ by Xu Hengchun, he says that, any product is an outcome of processing and reconstructing natural materials by human being for the realization of a certain goal based on the objective rule they have learned. When a product has realized its destined function, and its purposiveness and regularity attain unification, then it means that human being have obtained freedom. A kind of beauty is presented which is a typical form or which is a form of its freedom and can fully reflect this unified product, which is functional beauty. As a beauty of material substance created by human being in their production practice, functional beauty is the most fundamental and common aesthetic pattern, and is also a relatively elementary aesthetic pattern. With the help of functional beauty, works of art design can reproduce its material and structure, and bring into prominence its utility function and technological rationality, which enable people to enjoy physical and psychological joviality.

\section{Beauty of design in form}

Beauty in form is an abstract form of functional beauty, which refers to aesthetic characteristics manifested by natural quality (color, form and sound) of materials which constitute works of modern art design and their combination rules, such as proportion and rhythm, etc. beauty of material itself is natural beauty, such as brightness of the glass, its thoroughness, magnificence of jewelry, and its sumptuosity, pureness of white, vehemence of red and cleanness of blue, etc. Then, they are combined according to the following rules to constitute rules of beauty in form.

1). Order: a simplest formation rule. Its characteristics are unanimity and repetition, which is reflected as a unified order.

2). Balance: alternate repetition of different forms, colors and sounds, which bring into form beauty with both changes and unification.

3). Proportion: relationship between whole and part or relationship between part and part in a works of art. There are two sorts of existence forms, namely, proportion in space and proportion in time. The so-called golden section refers to the beautiful and classical proportion with an appropriate proportion of 8:5 or 1.618: 1 .

4). Contrast: Co-existence of opposition and unification at the same time in a works of art, which yields sharp-cut, outstanding and exhilarated feeling among people.

5). Rhythm: regular repetition of a certain element in a works of art and continuity in good order is formed.

6). Harmony: the highest level of pattern reflected by beauty of works in form. Pureness reflected within abundance and order resided in freedom.

From the foregoing, it is obvious that just as art activities, modern design also has been penetrated into several aspects of the social reality. Modern design expands and splits out functions and tasks which are similar but somewhat different 
from the original realm of art, that is, aesthetic value and art function. It can be said that, in a modern technical situation, boundary between technical products and art products is often fuzzy and uncertain. Any technical product can not only be an art product, but is also likely to be an artistic product, because any of them is brought into form by human being with consciousness in accordance with a certain morphological meaning. Many objects, with appropriate design, can integrate the aesthetic element and functional element together in an organic way. What is more important, they can be changed in forms together with intention or attitudes of users and audience. That is to say, a technical product can be changed into an art product in the same way as flying carriers of modern space flight and aviation, automobile and steamship etc, which do not lag a little bit behind the artwork collected in a common art gallery in terms of their breath-taking speed and creative imagination. There are quite a great many such cases. The achievements of product design or environmental design are themselves component elements of the beauty of the surrounding, and they are just like a unit cell within the surrounding, which also have their aesthetic value. What should be emphasized is that, all technical products which correspond with requirements of the goal, such as man-made mechanical products, although they are not designed purely for an artistic goal, they can, and they should become the targets of aesthetic reflection whether they are within the realm of art or are within the realm of non-art. And they all have their aesthetic significance. What's more, they are the motive and source of the aesthetic activity and aesthetic experiences of human being. Designers at present are just as artists, who endow a product with such-and-such morphological characters, and who arouse a certain aesthetic impression or aesthetic implication during the process of conversion with human being, which is completely possible. Today, industrial products verify the intellectual power of human being with their rationality. However, the design of a designer also better reflects demands of human being, and it enriches its aesthetic value with a new "personalized" significance. This is a special contribution of technical culture.

Design art is a branch in the developmental process of art, and it combines the functions of art and design, and also brings art form and art technique into service for the functionality so as to satisfy demands of the public life. Existence of design art enriches requirements of social material and spiritual of the public. Functionality and aesthetics, from beginning to end, are the characteristics for design art to be different from other art forms. It can be said that design art is a public art, and is also a practical art.

\section{References}

Jin, Baosheng. (1990). On Design Thinking, in Analects on Industrial Arts. Beijing: Beijing Art And Craft Press.

Li, Zehou. (1986). The Path of Beauty. Hefei: Anhui Literature \& Art Publishing House, 68.

Wang, Nana. (2003). Art Design and Cultural Identity. Academia Bimonthly, (5), 40.

Xu, Hengchun. (1989). Technological Aesthetics. Shanghai People's Publishing House, 7. 